\title{
Pengaruh Kejelasan Sasaran Anggaran, Pengendalian Akuntansi dan Sistem Pelaporan Terhadap Akuntabilitas Kinerja (Studi Empiris Koni Se Sumatera Barat)
}

\author{
Medelyn Sonya Mikoshi \\ Program Studi Magister Akuntansi Fak. Ekonomi Universitas Andalas \\ Correspondence email: medelyn.mikoshi@yahoo.com
}

\begin{abstract}
This research aimed to identify and to get empirical evidence of the effect of clarity of target budgets, control accounting, systems reporting on accountability performance. This study was 20 KONI registered in west sumatera with a total sample of 40 comprised of executive director and chairman of internal audit in the KONI field in west sumatera.This study uses the dependent variable of performance accountability and the independent variable is the clarity of the target budget, accounting controls and reporting systems. The hypothesis is tested by using multiple regression analysis using SPSS version 14.The test results show that accounting controls give a significant effect on accountability performance, while the budget goal clarity and reporting systems have no significant effect on accountability performance.
\end{abstract}

Keywords: Accountability Performance, Clarity of target budgets, Control Accounting, Systems reporting.

\section{PENDAHULUAN}

Setiap kegiatan organisasi harus dapat diukur dan dinyatakan keterkaitannya dengan pencapaian arah organisasi dimasa yang akan datang. Kegiatan organisasi ini dinyatakan dalam visi dan misi yang dibuat oleh organisasi. Adanya pengukuran tingkat keberhasilan suatu organisasi dalam bentuk mekanisme evaluasi, maka dapat diketahui kinerja suatu organisasi. Untuk mencapai visi dan misi yang telah ditetapkan melalui kegiatan, program atau kebijaksanaan dalam pemerintahan dibutuhkan pembagian wewenang atau pendelegasian yang tepat. Pergeseran sistem pemerintahan Republik Indonesia dari sentralisasi ke desentralisasi didukung oleh Undang-Undang Otonomi Daerah yang terdiri dari Undang-Undang Nomor 22 Tahun 1999 tentang Pemerintahan Daerah dan Undang-Undang Nomor 25 Tahun 1999 tentang Perimbangan Keuangan Pusat dan Daerah yang diberlakukan sejak Januari 2001. Fokusnya perhatian organisasi dari sektor publik terhadap isu kinerja, hal ini dimulai oleh pemerintah Amerika Serikat dengan memberikan prioritas utama dalam mengembangkan strategi baru terkait sistem pengukuran kinerja.

Komite Olahraga Nasional Indonesia yang disingkat dengan "KONI" merupakan organisasi yang didirikan pada 31 Desember 1966 berdasarkan pancasila dan Undang-Undang Dasar Negara Republik Indonesia Tahun 1945, KONI adalah satu-satunya organisasi keolahragaan nasional yang berwenang dan bertanggung jawab mengelola, membina, mengembangkan, dan mengoordinasikan setiap dan seluruh pelaksanaan kegiatan olahraga yang berhubungan dengan dunia olahraga internasional dapat berkoordinasi dengan lembaga terkait. KONI merupakan organisasi yang tidak berafiliasi dengan kekuatan politik maupun bersifat nirlaba. KONI mempunyai tujuan dalam mewujudkan prestasi olahraga yang membanggakan, membangun watak, mengangkat harkat dan martabat kehormatan bangsa dalam rangka ikut serta mempererat, membina persatuan dan kesatuan bangsa, serta memperkokoh ketahanan sosial.

Dalam Undang-Undang Republik Indonesia Nomor 3 Tahun 2005 tentang sistem keolahragaan nasional mengatakan bahwa pembinaan dan pengembangan keolahragaan nasional yang dapat menjamin penerapan akses terhadap olahraga, peningkatan kesehatan dan kebugaran, peningkatan prestasi, dan manajemen keolahragaan yang mampu menghadapi tantangan serta tuntutan perubahan kehidupan nasional dan global memerlukan sistem keolahragaan nasional. KONI mempunyai tugas (1) Membantu Pemerintah daerah dalam membuat kebijakan dalam bidang pengelolaan, pembinaan, dan pengembangan olahraga prestasi pada tingkat nasional maupun daerah, (2) Mengkoordinasikan induk organisasi cabang olahraga, organisasi olahraga fungsional, serta KONI Provinsi dan KONI Kabupaten/Kota. (3) Melaksanakan pengelolaan, pembinaan dan pengembangan olahraga prestasi berdasarkan kewenangannya. (4) Membantu dan mendukung penyelenggaraan single event / kejuaraan-kejuaraan yang diselenggarakan oleh anggota. (5) Melaksanakan evaluasi dan pengawasan untuk mencapai konsistensi antara kebijakan dan pelaksanaan. (6) menyebarluaskan semangat oliampiade. Adapun kegiatan / perlombaan yang dilaksanakan oleh KONI dalam menjalankan tugas dan mencapai tujuan, hal ini akan diuraikan di tabel 1 sebagai berikut: 
Medelyn Sonya Mikoshi, Pengaruh Kejelasan Sasaran Anggaran, Pengendalian Akuntansi dan Sistem Pelaporan Terhadap Akuntabilitas Kinerja (Studi Empiris Koni Se Sumatera Barat)

Tabel 1

Kegiatan rutin yang dilakukan oleh KONI

\begin{tabular}{lll}
\hline No & \multicolumn{1}{c}{ Jenis Kegiatan } & \multicolumn{1}{c}{ Waktu Pelaksanaan } \\
\hline 1. & KEJURDA (Kejuaraan Daerah) & Terus menerus \\
2. & PORKAB/PORKOT (Pekan Olahraga Kabupaten/Kota) & 1 kali dalam 2 tahun \\
3. & PORPROV (Pekan OLah Raga Provinsi) & 1 kali dalam 2 tahun \\
4. & PORWIL(Pekan OLahraga Wilayah) & 1 kali dalam 4 tahun \\
5. & KEJURNAS (Kejuaraan Nasional) & Dilakukan sebelum PON \\
6. & PON (Pekan Olahraga Nasional) & 1 kali dalam 4 tahun \\
\hline
\end{tabular}

Sumber; KONI Sumatera Barat

Tabel di atas, anggaran yang ditetapkan oleh KONI di Sumatera Barat hanya untuk kegiatan KEJURDA, PORKAB/PORKOT, dan PORPROV, untuk kegiatan PORWIL anggaranya ditetapkan oleh KONI Sumatera Barat, sedangkan untuk kegiatan KEJURNAS dan PON anggarannya di tetapkan oleh KONI pusat. Kegiatan yang dilaksanakan KONI di Sumatera Barat pada tahun ganjil yaitu PORKAB/PORKOT, sedangkan pada tahun genap yaitu kegiatan PORPROV. Dari 20 KONI yang terdaftar di Sumatera Barat, ada beberapa KONI yang mengalami permasalahan pada anggaran yang terjadi ditahun 2011, 2013, dan 2015, yaitu :

Tabel 2

Anggaran Masuk / Keluar KONI (Rp. 000)

\begin{tabular}{lcccrr}
\hline \multicolumn{1}{c}{ KONI } & Tahun 2011 & Tahun 2013 & Tahun 2015 & \% (2011 ke 2013) & \% (2013 ke 2015) \\
\hline Kota Padang & Rp. 1.415 .000 & Rp. 1.400 .000 & Rp. 1.387 .800 & 1,71 & 0,87 \\
Kab. Solok & Rp. 1.388 .000 & Rp. 1.380 .000 & Rp. 1.378 .000 & 0,15 \\
Kota Solok & Rp. 1.368 .500 & Rp. 1.360 .000 & Rp. 1.348 .000 & 0,63 & 1,48 \\
Kota Padang Panjang & Rp. 1.370 .000 & Rp. 1.350 .000 & Rp. 1.333 .000 & 1,88 & 0,26 \\
Kota Bukittinggi & Rp. 1.395 .800 & Rp. 1.370 .000 & Rp. 1.360 .000 & 0,73 \\
\hline
\end{tabular}

Sumber; KONI Sumatera Barat

Tabel diatas, persentase anggaran yang terjadi ditahun 2011, 2013, dan 2015 pada KONI Kota Padang mengalami penurunan yaitu dari $1,71 \%$ ke $0,87 \%$. Begitu juga pada KONI kab. Solok, yaitu dari 0,58\% ke $0,15 \%$. Berbeda pada KONI Kota Solok yang persentasenya, yaitu dari $0,63 \%$ ke $0,88 \%$. Sedangkan pada KONI Kota Padang Panjang yang terjadi adalah penurunan, yaitu dari 1,48\% ke 1,26\%. Begitu juga pada KONI Kota Bukittinggi, yaitu 1,88\% ke 0,73\%. Menurunnya anggaran pada tahun 2011 ke 2013 dan 2013 ke 2015 tersebut karena kurangnya dana dalam APBD Kab/Kota yang sangat tergantung pada Pendapatan Asli Daerah (PAD) dan kebijakan Legislatif (DPRD) dan Eksekutif (Bupati/Wako), yang disebabkan pemerintah menganggap kurang efektifnya KONI dalam pelaksanaan pelaporan dan pengendalian akuntansi. Akibatnya pertanggungjawaban pada kinerja organisasi KONI terganggu atau tidak terlaksana dengan sempurna.

Dalam pelaksanaan tugasnya, akuntabilitas publik merupakan pemberian informasi dan pengungkapan atas aktivitas dan kinerja keuangan organisasi kepada pihak-pihak yang berkepentingan dengan laporan tersebut Mahsun, (2006). Adanya Informasi dan pengungkapan tersebut, baik organisasi pusat maupun organisasi tingkat provinsi dan tingkat Kabupaten/Kota harus mau dan mampu menjadi subyek pemberi informasi atas aktivitas dan kinerja keuangan yang diperlukan secara akurat, relevan, tepat waktu, konsisten dan dapat dipercaya. Dalam menghadapi akuntabilitas tersebut, setiap organisasi perlu memperhatikan beberapa hal, antara lain anggaran, pengendalian akuntansi, efekrivitas pelaksanaan anggaran dan sistem pelaporan. Menurut Mardiasmo (2002) anggaran berfungsi sebagai: (1) alat perencanaan, (2) alat pengendalian, (3) alat kebijakan fiskal, (4) alat politik, (5) alat koordinasi dan komunikasi, (6) alat penilaian kinerja, dan (7) alat motivasi. Menurut Bastian (2006: 163), penyusunan anggaran dapat dikatakan baik apabila memenuhi persyaratan: (1) berdasarkan program, (2) berdasarkan pusat pertanggungjawaban dan (3) sebagai alat perencanaan dan pengendalian. Dalam hal ini setiap bidang-bidang yang terdapat pada KONI wajib melaporkan penyusunan anggaran dan menentukan sasaran anggaran pada setiap kegiatan yang dilakukan, dan menyampaikan laporan keuangan tahunan pada pertanggungjawaban keuangan rapat anggota KONI setelah dialakukan audit oleh akuntan publik.

Penelitian yang dilakukan oleh Septriane (2012) tentang Pengaruh kejelasan sasaran anggaran dan penerapan akuntansi sektor pablik terhadap akuntanbilitas kinerja, bahwa kejelasan sasaran anggaran berpengaruh signifikan terhadap akuntanbilitas kinerja. Begitu juga penelitian yang dilakukan Darwanis dan Sephi (2013) tentang Akuntanbilitas Kinerja Instansi Pemerintah Bahwa Kejelasan Sasaran Anggaran Berpengaruh Signifikan Terhadap Akuntanbilitas Kinerja Pemerintah. Penelitian yang dilakukan oleh Herawaty (2011) tentang Pengaruh kejelasan sasaran anggaran, pengendalian akuntansi, dan sistem pelaporan terhadap akuntabilitas kinerja instansi pemerintah daerah bahwa kejelasan sasaran anggaran tidak berpengaruh terhadap akuntabilitas kinerja. 
Anggaran merupakan rencana kerja organisasi dimasa mendatang yang mewujudkan dalam bentuk kuantitatif dan formal. Namun kenyataannya KONI di Sumatera Barat belum sepenuhnya mengoptimalisasikan anggaran yang di inginkannya, maka para karyawan harus menetapkan pengendalian akuntansi agar dapat mengoptimalisasi akuntabilitas kinerja para karyawan KONI di Sumatera Barat. Pada penelitian terdahulu yang dilakukan oleh Herawaty (2011) tentang Pengaruh kejelasan sasaran anggaran, pengendalian akuntansi, dan sistem pelaporan terhadap akuntabilitas kinerja instansi pemerintah daerah bahwa pengendalian akuntansi tidak berpengaruh terhadap akuntabilitas kinerja. Sedangkan penelitian yang dilakukan oleh Wina dan Siti (2013) tentang Pengaruh penerapan standar pelaporan akuntansi sektor publik dan pengawasan kualitas laporan keuangan terhadap akuntanbilitas kinerja instansi pemerintah bahwa Penerapan standar pelaporan akuntansi sektor publik, dan pengawasan kualitas laporan keuangan berpengaruh terhadap akuntabilitas kinerja instansi pemerintah. Penelitian yang dilakukan oleh Ardianto (2014) tentang Pengaruh Penerapan akuntanbilitas keuangan, pemanfaatan teknologi informasi, kompentensi aparatur pemerintah daerah dan ketaatan terhadap peraturan perundangan terhadap akuntanbilitas kinerja instansi pemerintah bahwa penerapan akuntanbilitas, pemanfaatan teknologi informasi, kompetensi aparat, ketaatan dan peraturan berpengaruh terhadap akuntabiulitas kinerja. Tujuan penelitian ini adalah untuk memperoleh bukti empiris mengenai pengaruh kejelasan sasaran anggaran, pengendalian akuntansi dan sistem pelaporan terhadap akuntabilitas kinerja KONI se Sumatera Barat.

\section{Landasan Teori \\ Teori Transparansi}

Transparansi adalah adanya kebijakan terbuka bagi pengawasan. Sedangkan yang dimaksud dengan informasi adalah informasi mengenai setiap aspek kebijakan organisasi pemerintah yang dapat dijangkau publik. Keterbukaan informasi diharapkan akan menghasilkan persaingan politik yang sehat, toleran dan kebijakan dibuat berdasarkan preferensi publik. Menurut Mardiasmo (2002) transparansi berarti keterbukaan organisasi pemerintah dalam memberikan informasi yang terkait dengan aktivitas pengelolaan sumber daya publik kepada pihak-pihak yang membutuhkan informasi.

\section{Akuntabilitas}

Mahsun, (2006) Akuntabilitas dapat dipahami sebagai kewajiban pihak pemegang amanah untuk memberi pertanggungjawaban, menyajikan, melaporkan, dan mengungkapkan segala aktivitas dan kegiatan yang menjadi tanggungjawabnya kepada pihak pemberi amanah yang memiliki hak dan kewenangan untuk meminta pertanggungjawaban tersebut.

\section{Akuntanbilitas Kinerja}

Bastian, (2010) Akuntabilitas kinerja merupakan salah satu kunci bagi terwujudnya good governance dalam pengelolaan organisasi publik. Akntabilitas kinerja telah menjadi salah satu item yang tercantum didalam dasar hukum atau aturan organisasi, karena organisasi diwajibkan secara hukum untuk memenuhi akuntabilitas organisasinya dengan kinerja yang diperolehnya. Pengertian akuntabilitas ini memberikan suatu petunjuk sasaran pada hampir semua reformasi sektor publik dan mendorong pada munculnya tekanan untuk pelaku kunci yang terlibat untuk pertanggungjawaban dan untuk menjamin kinerja pelayanan publik yang baik.

\section{Kejelasan Sasaran Anggaran}

Bastian, (2006) menyatakan Perencanaan merupakan bagian yang tak dapat dipisahkan dari proses manajemen organisasi. demikian juga, anggaran mempunyai posisi sangat penting, anggaran mengungkapkan apa yang akan dilakukan dimasa mendatang. Pemikiran strategi di setiap organisasi adalah proses dimana manajemen berpikir tentang pengintegrasian aktivitas kearah tujuan organisasi. Anggaran dapat diinterprestasikan sebagai paket pernyataan perkiraan penerimaan dan pengeluaran yang diharapkan akan terjadi dalam satu atau beberapa periode mendatang. Anggaran selalu menyertakan data penerimaan dan pengeluaran yang terjadi dimasa lalu.

\section{Pengendalian Akuntansi}

Baridwan (2001) Pengendalian akuntansi merupakan bagian dari pengendalian internal yang merupakan struktur organisasi dan semua cara-cara serta alat-alat yang dikoordinasikan yang digunakan didalam perusahaan dengan tujuan untuk menjaga keamanan harta milik perusahaan, memajukan efisiensi didalam operasi, dan membantu menjaga dipatuhinya kebijaksanaan manajemen yang telah ditetapkan lebih dahulu. 


\section{Sistem Pelaporan}

Bastian (2010) menyatakan "pelaporan kinerja merupakan refleksi kewajiban untuk mempresentasikan dan melaporkan kinerja semua aktivitas serta sumber daya yang harus dipertanggungjawabkan. Pelaporan ini merupakan wujud dari proses akuntabilitas kinerja". Setiap instansi berkewajiban untuk menyiapkan, menyusun, dan melaporkan laporan keuangan secara tertulis, periodik dan melembaga.

\section{Pengembangan Hipotesis \\ Pengaruh Kejelasan Sasaran Anggaran Terhadap Akuntabilitas Kinerja}

Kejelasan sasaran anggaran merupakan suatu rencana operasi keuangan, yang mencakup estimasi pengeluaran yang diusulkan, dan sumber pendanaan yanf diharapkan untuk membiayai dalam waktu periode tertentu yang dipertanggungjawabkan oleh suatu lembaga tertentu. Penelitian yang dilakukan oleh Herawaty (2011) dibuktikan bahwa tidak terdapat pengaruh signifikan antara kejelasan sasaran anggaran terhadap akuntabilitas kinerja. Sedangkan berbeda dengan penelitian yang dilakukan oleh Septriane (2012) bahwa terdapat pengaruh positif dan signifikan antara kejelasan sasaran anggaran terhadap akuntabilitas kinerja.

H1 : Kejelasan Sasaran Anggaran Berpengaruh Terhadap Akuntabilitas Kinerja

\section{Pengaruh Pengendalian Akuntansi Terhadap Akuntabilitas Kinerja}

Dalam PP No 60 tahun 2008 tersebut kegiatan pengendalian membantu memastikan bahwa arah pimpinan instansi pemerintah dilaksanakan. Kegiatan pengendalian harus efektif dan efisien dalam pencapaian tujuan organisasi serta sesuai dengan ukuran. Penelitian yang dilakukan oleh Herawaty (2011) bahwa pengendalian akuntansi tidak berpengaruh signifikan terhadap akuntabilitas kinerja. Sedangkan menurut Primayoni dkk (2014) mengatakan bahwa pengendalian akuntansi berpengaruh positif dan signifikan terhadap akuntabilitas kinerja.

H2 : Pengendalian Akuntansi Berpengaruh terhadap Akuntabilitas kinerja

\section{Pengaruh sistem pelaporan Terhadap Akuntabilitas Kinerja}

Sebagai pengambil keputusan dan penanggungjawab tertinggi di dalam organisasi, manajer puncak mendelegasikan tugas dan kewenangan kepada manajer/pimpnan unit di bawahnya. Manajer/pimpinan unit yang menerima wewenang, mempertanggungjawabkan kewenangan dan tugas yang diterimanya kepada pemberi wewenang. Akuntansi pertanggung jawaban adalah sistem yang mengukur hasil tiap pusat pertanggung jawaban sesuai informasi yang pimpinan/manajer untuk pusat operasi mereka. Penelitian yang dilakukan oleh Herawaty (2011) bahwa sistem pelaporan berpengaruh signifikan terhadap akuntabilitas kinerja. Penelitian yang dilakukan Anjarwati (2012) mengatakan sistem pelaporan berpengaruh terhadap akuntabilitas kinerja pemerintah.

H3 : Sistem Pelaporan Berpengaruh terhadap Akuntabilitas kinerja

\section{METODE}

Populasi (population) mengacu pada keseluruhan kelompok orang, kejadian, atau hal minat yang ingin peneliti investigasi (Sekaran, 2011). Populasi dalam penelitian ini adalah 20 KONI yang terdaftar di Sumatera Barat. Pengambilan sampel dalam penelitian ini menggunakan teknik purposive sampling yang merupakan salah satu teknik pengambilan sampel yang sering digunakan dalam penelitian. Jenis data yang digunakan dalam penelitian ini adalah data primer, yaitu data yang diperoleh secara langsung dari sumber asli (tidak melalui media perantara). Data primer secara khusus dikumpulkan oleh penulis untuk menjawab pertanyaan peneliti, kuesioner disebar dengan mengantar langsung ke KONI Sumatera Barat. Teknik pengumpulan data dalam penelitian ini menggunakan instrument kuesioner dengan memberikan daftar pertanyaan tertulis kepada resoponden, yaitu yang terlibat dalam proses keuangan dan anggaran yang terdiri dari ketua harian dan ketua bidang internal audit pada KONI di Sumatera Barat untuk mengukur kejelasan sasaran anggaran, pengendalian akuntansi, dan sistem pelaporan terhadap akuntabilitas kinerja.

\section{Variabel Penelitian dan Defenisi Operasional}

Kejelasan Sasaran Anggaran

Kejelasan sasaran anggaran adalah suatu rencana operasi keuangan, yang mencakup estimasi pengeluaran yang diusulkan, dan sumber pendanaan yang diharapkan untuk membiayai dalam waktu periode tertentu. Variabel ini diukur menggunakan instrumen yang sama seperti yang digunakan oleh Herawaty (2011) jumlah kuesioner terdapat 7 pertanyaan dengan menggunakan 5 skala likert. 
Medelyn Sonya Mikoshi, Pengaruh Kejelasan Sasaran Anggaran, Pengendalian Akuntansi dan Sistem Pelaporan Terhadap Akuntabilitas Kinerja (Studi Empiris Koni Se Sumatera Barat)

\section{Pengendalian Akuntansi}

Pengendalian akuntansi merupakan sistem pengendalian internal yang menekankan pada tindakan pencegahan untuk mengurangi kekeliruan (tidak sengaja) dan ketidakberesan (sengaja). Agar terciptanya sistem pelaporan keuangan yang baik. Variabel ini diukur menggunakan instrument yang sama seperti yang digunakan oleh Herawaty (2011) jumlah kuesioner terdapat 4 pertanyaan dengan menggunakan 5 skala likert.

\section{Sistem Pelaporan}

Sistem pelaporan merupakan laporan yang menggambarkan sistem pertanggung jawaban dari bawahan (pimpinan unit anggaran) kepada atasan (kepala bagian anggaran). Variabel ini diukur menggunakan instrument yang sama seperti yang digunakan oleh Herawaty (2011) jumlah kuesioner terdapat 3 pertanyaan dengan menggunakan 5 skala likert.

\section{Akuntabilitas Kinerja}

Akuntabilitas kinerja merupakan kewajiban untuk menyajikan dan melaporkan segala tindakan lanjut dan kegiatan seseorang atau lembaga kepada pihak yang lebih tinggi.

Variabel ini diukur menggunakan instrumen yang sama seperti yang digunakan oleh Sherillia (2012) jumlah kuesioner terdapat 4 pertanyaan dengan menggunakan 5 skala likert.

\section{Metode Analisis Data}

Statistik deskriptif digunakan untuk memberikan informasi mengenai karakteristik variabel penelitian yang utama dan daftar demografi responden. Statistik deskriptif memberikan gambaran atau deskripsi suatu data yang dilihat rata-rata (mean), standar deviasi, varian, maksimum, minimum, sum, range, kurtosis dan skewness (kemencengan distribusi) (Ghozali, 2013).

\section{Uji Kualitas Data}

Ketetapan pengujian suatu hipotesis tentang hubungan variabel penelitian sangat tergantung pada suatu kualitas data yang dipakai dalam pengujian tersebut. Menurut Ghozali (2013), ada dua uji kualitas data yaitu uji validitas dan uji reliabilitas.

\section{Uji Asumsi Klasik}

Sebelum melakukan pengujian hipotesis dengan menggunakan analisis regresi berganda, maka diperlukan pengujian asumsi klasik, uji asumsi klasik terdiri dari uji normalitas, uji multikolinearitas dan uji heteroskedastisitas.

\section{Uji Regresi Linear Berganda}

Analisis regresi digunakan untuk mengetahui bagaimana variabel dependent dapat diprediksi melalui variabel - variabel independen secara individual ataupun secara bersama-sama.

$$
\mathrm{Y}=\alpha+\beta 1 \mathrm{X} 1+\beta 2 \mathrm{X} 2+\beta 2 \mathrm{X} 3+\varepsilon
$$

Keterangan: $\mathrm{Y}=$ Akuntabilitas Kinerja; $\alpha=$ Konstanta; $\beta 1, \beta 2,=$ Koefisien Regresi; $\mathrm{X} 1=$ Kejelasan sasaran anggaran; $\mathrm{X} 2=$ Pengendalian Akuntansi; X3 = Sistem Pelaporan; $\varepsilon=$ Error Term

\section{HASIL}

Statistik deskriptif digunakan untuk memberikan informasi mengenai karakteristik variabel penelitian yang utama dan daftar demografi responden.

Tabel 3

Hasil Uji Deskriptif

\begin{tabular}{lrrrr}
\hline \multicolumn{1}{c}{ Variabel } & Kisaran teritis & \multicolumn{1}{c}{ Kisaran actual } & \multicolumn{1}{c}{ mean } & Std. Deviation \\
\hline Akuntabilitas Kinerja (Y) & $2-10$ & $5-10$ & 7,1750 & 1,33757 \\
Kejelasan Sasaran Anggaran (X1) & $4-20$ & $4-20$ & 15,5000 & 2,85549 \\
Pengendalian Akuntansi (X2) & $3-15$ & $9-20$ & 14,4000 & 2,57004 \\
Sistem Pelaporan (X3) & $2-10$ & $3-10$ & 7,5250 & 1,72445 \\
\hline
\end{tabular}

Sumber: data olahan

Analisis deskriptif digunakan untuk memudahkan penelitian dalam merangkum hasil penelitian, pada tabel diatas dapat di simpulkan bahwa kisaran teritis antara 2 s/d 20, kisaran aktual berkisar antara 3 s/d 20 dan nilai mean 
berkisar antara 7,1750 s/d 15,5000 sedangkan std. Deviationnya berkisar antara1,33757 s/d 2,85549. Berdasarkan hasil pengujian validitas dan reliabilitas menunjukkan bahwa seluruh pernyataan baik variabel independen (kejelasan sasaran anggaran, pengendalian akuntansi dan sistem pelaporan), maupun variabel dependen (akuntabilitas kinerja) dinyatan valid dan reliabel.

\section{Uji Asumsi Klasik}

Berdasarkan hasil pengujian menunjukkan bahwa seluruh pernyataan baik variabel independen (kejelasan sasaran anggaran, pengendalian akuntansi dan sistem pelaporan), maupun variabel dependen (akuntabilitas kinerja) dinayakan normal. Serta hasil uji multikolinearitas dan uji heteroskedastisitas menunjukan bahwa dalam penelitian ini tidak mengalami masalah multikolinearitas dan heteroskedastisitas.

\section{Pengujian Hipotesis}

\section{Hasil Uji Koefisien Determinasi $\left(R^{2}\right)$}

R Square sebesar 0,837 (83,7\%). Hal ini menerangkan bahwa pengaruh variabel kejelasan sasaran anggaran, pengendalian akuntansi dan sistem pelaporan terhadap variabel akuntabilitas kinerja KONI se Sumatera Barat sebesar $83,7 \%$. Atau variasi variabel bebas yang digunakan mampu menjelaskan sebesar $83,7 \%$ variasi variabel dependen, sedangkan sisanya sebesar $16,3 \%$ menggambarkan variabel-variabel bebas lainya yang tidak diamati dalam penelitian ini.

\section{Hasil Uji F}

Berdasarkan hasil pengujian secara simultan, diketahui bahwa $\mathrm{F}$ hitung yang diperoleh adalah sebesar 61,762 yang diperkuat nilai signifikansi 0,000 . Nilai signifikansi $<\alpha 0,05$ maka keputusannya adalah hipotesis diterima sehingga dapat disimpulkan bahwa Kejelasan Sasaran Anggaran, Pengendalian Akuntansi dan Sistem Pelaporan secara bersamaan berpengaruh signifikan terhadap Akuntabilitas Kinerja.

\section{Hasil Uji t-tes Statistik}

Uji t-tes statistik pada dasarnya menunjukkan seberapa jauh pengaruh satu variabel penjelas atau independen secara individual dalam menerangkan variabel dependen (Ghozali, 2013:98). Dengan $\alpha=5 \%$ apabila Sig t $<0,05$ maka hipotesis diterima, sebaliknya apabila Sig t $>0,05$ hipotesis ditolak. Hasil dari SPSS dapat dilihat pada tabel berikut:

Tabel 4

Hasil Uji t-tes Statistik

\begin{tabular}{lrrr}
\hline Variabel Bebas dan Konstanta & Koefisien Regresi & Signifikansi & Keterangan \\
\hline Konstanta &,- 340 &, 736 & H1 Ditolak \\
Kejelasan Sasaran Anggaran (X1) & 1,055 &, 298 & H2 Diterima \\
Pengendalian Akuntansi (X2) & 13,420 &, 000 & ,851 \\
Sistem pelaporan (X3) &, 189 & Hitolak \\
\hline
\end{tabular}

Sumber: data olahan

\section{Persamaan Regresi Linear Berganda}

Tabel diatas terlihat uji signifikan t-tes statistik untuk menghasilkan nilai:

$\mathrm{Y}=-0,340+1,055 \mathrm{X}_{1}+13,420 \mathrm{X}_{2}+0,189 \mathrm{X}_{3}$

\section{Pengaruh Kejelasan Sasaran Anggaran terhadap Akuntabilitas Kinerja}

Berdasarkan Tabel 4 dapat dilihat bahwa nilai Sig 0,298. Nilai Sig > 0,05 sehingga dapat disimpulkan bahwa variabel Kejelasan Sasaran Anggaran tidak berpengaruh signifikan terhadap Akuntabilitas Kinerja KONI di Sumatera Barat, berarti H1 ditolak pada penelitian ini. Pada organisasi KONI di Sumatera Barat anggaran APBD yang digunakan tidak dapat terukur dengan baik dari waktu penggunaan ataupun dari cara menggunakannya, karena kesuksesan kinerja KONI dilihat dari cabang-cabang olahraga dalam melaksanakan pertandingan, kinerja diupayakan maksimal sehingga akuntabilitas kinerja lebih ditentukan oleh prestasi dan kesungguhan.

\section{Pengaruh Pengendalian Akuntansi terhadap Akuntabilitas Kinerja}

Berdasarkan table 4 dapat dilihat bahwa nilai Sig 0,000. Nilai Sig <0,05 sehingga dapat disimpulkan bahwa Pengendalian Akuntansi berpengaruh signifikan terhadap Akuntabilitas Kinerja KONI di Sumatera Barat, berarti H2 diterima dalam penelitian ini. Dengan adanya pengendalian akuntansi diharapkan proses yang dilakukan dalam manajemen organisasi menjamin bahwa sumber daya digunakan secara ekonomis, efisien dan efektif dengan 
Medelyn Sonya Mikoshi, Pengaruh Kejelasan Sasaran Anggaran, Pengendalian Akuntansi dan Sistem Pelaporan Terhadap Akuntabilitas Kinerja (Studi Empiris Koni Se Sumatera Barat)

menerima umpan balik berupa kinerja sesungguhnya dan mengambil tindakan yang diperlukan jika kinerja yang dilakukan berbeda dengan apa yang telah direncanakan sebelumnya demi meningkatkan pertanggungjawaban kinerja organisasi.

\section{Pengaruh Sistem Pelaporan terhadap Akuntabilitas Kinerja}

Berdasarkan tabel 4 dapat dilihat bahwa nilai Sig 0,851. Nilai Sig >0,05 sehingga dapat disimpulkan bahwa Sistem Pelaporan tidak berpengaruh signifikan terhadap Akuntabilitas Kinerja, berarti $\mathrm{H} 3$ ditolak dalam penelitian ini. Akuntabilitas kinerja lebih terlihat pada upaya prestasi KONI, sistem pelaporan tidak dapat mengukur pertanggungjawaban kinerja KONI karena pertanggungjawaban KONI di ukur dari sejauhmana KONI Kabupaten/Kota terseleksi untuk event berikutnya bukan pada pelaporan setiap jenjang-jenjang kegiatan KONI.

\section{SIMPULAN}

Setelah melakukan analisis dan pengujian hipotesis, maka dapat ditarik kesimpulan sebagai berikut:

1. Secara parsial (individu) Kejelasan Sasaran Anggaran tidak berpengaruh terhadap Akuntabilitas Kinerja KONI di Sumatera Barat.

2. Secara parsial (individu) Pengendalian Akuntansi berpengaruh terhadap Akuntabilitas Kinerja KONI di Sumatera Barat.

3. Secara parsial (individu) Sistem Pelaporan tidak berpengaruh terhadap Akuntabilitas Kinerja KONI di Sumatera Barat.

4. Secara simultan (bersama-sama) uji signifikansi nilai F menunjukkan hasil keputusan hipotesis diterima sehingga dapat disimpulkan bahwa Kejelasan Sasaran Anggaran, Pengendalian Akuntansi dan Sistem Pelaporan berpengaruh signifikan terhadap Akuntabilitas Kinerja KONI di Sumatera Barat.

5. Uji koefisien determinasi $\left(\mathrm{R}^{2}\right)$ digunakan untuk mengukur seberapa besar peranan variabel independen terhadap variabel dependen. Dapat dilihat dari hasil $\mathrm{R}$ square maka dapat disimpulkan bahwa variabel independen mampu menjelaskan variabel dependen.

6. Model regresi berganda yang digunakan dalam penelitian ini dinilai sudah cukup layak untuk digunakan karena telah memenuhi seluruh pengujian asumsi klasik yang meliputi : terjadi normalitas, tidak terjadi multikolinearitas dan tidak terdapat gejala Heteroskedastisitas.

\section{DAFTAR PUSTAKA}

Anjarwati, Mei. (2012). Pengaruh Kejelasan Sasaran Anggaran, Pengendalian Akuntansi dan Sistem Pelaporan terhadap Akuntabilitas Kinerja Instansi Pemerintah. Vol. 1, No. 2, ISSN 2252-6765.

Ardianto, Rofika. (2014). Pengaruh Penerapan Akuntabilitas Keuangan, Pemanfaatan Teknologi Informasi, Kompetensi Aparatur Pemerintah Daerah dan Ketaatan Terhadap Peraturan Perundangan Terhadap Akuntabilitas Kinerja Instansi Pemerintah. Vol. 2, No.2, ISSN 2337-4314.

Bastian, Indra, (2010) Akuntansi Sektor Publik, suatu pengantar. Edisi ketiga. Jakarta : Erlangga.

Baridwan, Zaki. (2001). Sistem Informasi Akuntansi. Edisi Pertama. Yogyakarta. BPEF.

BPKP. (2000). Akuntabilitas Instansi Pemerintah. Edisi Kelima. BPKP.

BPKP. (2011). Modul Akuntabilitas Instansi Pemerintah. Edisi Keenam. Bogor: Pusat Pendidikan Pelatihan dan Pengawasan BPKP.

Cahyani, Ni Made Mega dan I Made Karya Utama. (2015). Pengaruh Kejelasan Sasaran Anggaran, Pengendalian Akuntansi dan Sistem Pelaporan Pada Akuntabilitas Kinerja. ISSN: 2302-8556. Vol. 10. No.3.

Darwanis, dan Sephi Chairunnisa. (2013). Jurnal Telaah \& Riset Akuntansi. Akuntanbilitas kinerja Instansi Pemerintah. Vol. 6, No.2.

Endrayani, Komang Sri. Made Pradana Adiputra. Dan Nyoman Ari Surya (2014). Pengarung Penerapan Anggaran Berbasis Kinerja terhadap Akuntabilitas Kinerja instansi Pemerintah (Studi Kasus pada Dinas Kehutanan UPT KPH Bali Tengah Kota Singaraja). Vol. 2. No. 1.

Ghozali, Imam. (2013). SPSS 21. Aplikasi Analisis Multivariate dengan Program SPSS. Edisi ketujuh. Semarang. Unversitas Diponegoro.

Halim, Abdul dan M. Syam Kusufi. (2014). Akuntansi Sektor Publik. Yogyakarta. Salemba Empat.

Herawaty, Netty. (2011). Pengaruh Kejelasan Sasaran Anggaran, Pengendalian Akuntansi dan Sistem Pelaporan Terhadap Akuntabilitas Kinerja Instansi Pemerintah Daerah Kota Jambi. Vol. 13, No. 2, ISSN 0852-8349.

Hidayattullah, Afilu dan Irine Herdjiono. (2015). Pengaruh Kejelasan Sasaran Anggaran. Pengendalian Akuntansi. Sistem Pelaporan Terhadap Akuntabilitas Kinerja SKPD di Merauke. ISBN: 978-979-3649-81-8.

Krina, P. (2003). Indikator dan alat ukur prinsip akuntabilitas transaparansi dan partisipasi. Jakarta : sekretariat Good Publik Governance. Badan pembangunan nasional. 
Medelyn Sonya Mikoshi, Pengaruh Kejelasan Sasaran Anggaran, Pengendalian Akuntansi dan Sistem Pelaporan Terhadap Akuntabilitas Kinerja (Studi Empiris Koni Se Sumatera Barat)

Lembaga Administrasi Negara (LAN), 2003, "Pedoman Penyusunan Pelaporan Akuntabilitas Kinerja Instansi Pemerintah". Jakarta.

Mahsun, Mohamad. (2006). Pengukuran Kinerja Sektor Publik. Edisi Pertama. Yogyakarta. Universitas Gadjah Mada. Mardiasmo. (2002). Akuntansi Sektor Publik: Edisi keempat. Yogyakarta : ANDI.

Narko. (2007). Sistem Akuntansi.Edisi 5. Yayasan Pustaka Nusantara. Yogyakarta.

Primayoni, Ni Kadek Rina. Dkk. (2014). e-Journal S1 Ak Universitas Pendidikan Ganesha Jurusan Akuntansi, Pengaruh Kejelasan Sasaran Anggaran dan evektivitas Pengendalian internal terhadap Akuntabilitas Kinerja Instansi Pemerintah. Vol. 2, No. 1.

Rama, Dasaratha V. dan Jones, Frederick L. (2008). SISTEM INFORMASI AKUNTANSI. Buku Satu. (Alih bahasa M. Slamet Wibowo), Jakarta. Salemba Empat.

Rofika, dan Ardianto. (2014). Pengaruh Penerapan Akuntabilitas Keuangan, Pemanfaatan Teknologi Informasi, Kompetensi Aparatur Pemerintah Daerah dan Ketaatan Terhadap Peraturan Perundangan Terhadap Akuntabilitas Kinerja Instansi Pemerintah. ISSN: 2337-4314. Vol. 2. No.2.

Rosjidi. (2002). Akuntansi Sektor Publik, Yogyakarta : Andi.

Septriane, Sherillia. (2012). Pengaruh Kejelasan Sasaran Anggaran dan Penerapan Akuntansi Sektor Publik Terhadap Akuntabilitas Kinerja DPRD kota bandung.

Silvia. (2013). Pengaruh Keterbatasan Sistem Informasi, Komitmen Manajemen, dan Otoritas Pengambilan Keputusan Terhadap Akuntabilitas Kinerja instansi Pemerintah SKPD. ISSN 0852-8349. Vol. 13. No. 2. Kota Payakumbuh.

Susilowati, Harini. (2014). Pengaruh Kejelasan Sasaran Anggaran, Pengendalian Akuntansi, Sistem Pelaporan, dan Motivasi Kerja terhadap Akuntabilitas Kinerja Pemerintah Daerah. Universitas Muhammadiayah Surakarta.

Umar, Sekaran. (2011). Metode Riset Bisnis. Jakarta. Salemba Empat.

Wina, Intan Permata Haska dan Siti Khairani. (2013). Pengaruh Penerapan Standar Pelaporan Akuntansi Sektor Publik dan Pengawasan Kualitas Laporan Keuangan Terhadap Akuntabilitas Kinerja Instansi Pemerintah. Palembang.

Wahyuni, Raja Adri Satriawan Surya, dan Enni Savitri. (2014). Pengaruh Kejelasan Sasaran Anggaran, Pengendalian Akuntansi, dan Sistem Pelaporan terhadap Akuntabilitas Kinerja instansi Pemerintah. (Studi Pada Satuan Kerja Perangkat Daerah Kabupaten Rokan Hulu). Vol. 1. No. 1.

Yayasan Pembaruan Administrasi Publik Indonesia (YPAPI). (2004). Memahami Good Government. Yogyakarta. 